Bojan Krstić ${ }^{1}$

University of Niš, Faculty of Economics

SCIENTIFIC REVIEW ARTICLE

doi:10.5937/ekonomika1503031K

Ernad Kahrović ${ }^{2}$

Received: June 8, 2015

State University of Novi Pazar, Department of Economic Sciences Accepted: August 8, 2015

\title{
BUSINESS PROCESS OUTSOURCING AS A TOOL FOR IMPROVING ENTERPRISE EFFICIENCY
}

\begin{abstract}
The purpose of this paper is pointing out the relevance of outsourcing of business process project and strategic option for improving enterprise efficiency and realizing the competitive advantage. The aim of the paper is designing a conceptual model for implementation of BPO concept, which contains four generic steps: establish a business process outsourcing team, conduct a business process analysis, determine BPO possibilities, develop and present the business plan of BPO. The proposed model helps the clients and service provider organizations in understanding critical steps in realizing the intended $B P O$ project.
\end{abstract}

Key words: business process, management, outsourcing

JEL classification: M11, M21, O31

\section{АУТСОРСИНГ ПОСЛОВНИХ ПРОЦЕСА КАО АЛАТ ЗА УНАПРЕЪЕЊЕ ЕФИКАСНОСТИ ПРЕДУЗЕһА}

\section{Апстракт}

Сврха овог рада је да истакне значај пројекта и стратегијске опичје аутсорсинга пословних прочеса за унапређење ефикасности предузећа и остваривање конкурентске предности. Циљ рада је дизајнирање модела за примену кониепта аутсорсинга пословних прочеса, који се састоји од четири корака: планирање аутсорсинга процеса, дефинисање тима задужсеног за аутсорсинг, откривање потенцијалних могућности, као и развијање плана аутсорсинга. Предложени модел је од помоћи предузећима која користе стратегију аусорсинга прочеса, као и предузећима пружаочиима услуга аусорсинга у разумевању критичних корака у реализацији пројекта аутсорсинга прочеса.

Кључне речи: пословни процеси, управљање, аутсорсинг

\footnotetext{
${ }^{1}$ bojan.krstic@eknfak.ni.ac.rs

2 ekahrovic@np.ac.rs
} 


\section{Introduction}

Outsourcing has become an important business tool over the past decade. It is an arrangement in which one organization provides services to another organization that could also be or usually have been provided in-house. A competitive advantage may be gained when products or services are produced more efficiently and effectively by outside service (process or activity) providers. More and more large and small companies are turning to outsourcing as a grow method or strategy with the aim of controlling of overhead costs, restraining payroll and better access to outside knowledge. Outsourcing can provide companies to use resources efficiently and effectively by using the industry best practices and improve their business processes, enter or create new markets. Business process outsourcing secured from external providers, bring enterprises (which use this strategy) extensive world-class competencies and resources to meet the requirements and needs of their internal and, especially, external customers. Cooperating with a superior service (business process) provider can offer access to new technology, knowledge, intellectual and other material resources that the client may not own.

\section{The levels, drivers and types of outsourcing}

There are three levels of outsourcing - tactical, strategic and transformational.

Tactical outsourcing is used by companies to determine and solve specific problems. Regularly the firm is already in "problems" and outsourcing is seen as an immediate approach to address them. Regular problems are the following (Brown \& Wilson, 2005, p. 20): the lack of financial resources, deficient internal managerial competence, an absence of talent, or a desire to downsize, etc. Tactical outsourcing is a type of traditional outsourcing and is taking into account cost control and the makeor-buy decision. The tactical outsourcing results in obvious advantages as cash savings, cash infusion from the sale of assets, etc. (Ghodeswar \& Vaidyanathan, 2008, p. 26).

The outsourcing activity becomes strategic when it is adjusted to the organization's long-term corporate or business strategies, and when the advantages of outsourcing project will rise. Strategic outsourcing is relevant for an enterprise and its future core capabilities, organizational structure/architecture, cost, business performance and competitive position (Maurice \& Greaver, 1999, p. 8).

Transformational outsourcing is defined as a long-term relationship through which a service provider assists the client in stimulating continuous business change while also achieving operational effectiveness. This level of outsourcing is an emerging practice, where organizations are looking outside for help for more fundamental reasons - to encourage quick organizational change, implement new strategies, and reshape company boundaries.

Transformational outsourcing places the ability to convey new capacities to the organization squarely in the hands of executives who have and value these capabilities. In other words, the outsourcing partner provides a management team that is experienced in the capability that the organization seeking change needs. Also, those executives are empowered by the outsourcing process to implement the practice they bring with them (Chew \& Gottschalk, 2013, p. 338). 
A large number of studies have analysed the drivers of outsourcing. While many drivers are unique to specific companies and industries, there are some common key factors that motivate companies of all industries to make outsourcing decisions. These factors can broadly be categorized as economic, strategic and environmental (Table 1).

Outsourcing has three clear types since it initially created: a) manufacturing outsourcing, b) information technology (IT) outsourcing and c) business process outsourcing (BPO) (Mahmoodzadeh et al., 2009, p. 846).

Manufacturing outsourcing, which has become strategically important, refers to the process of determining which of the various manufacturing activities ought to be offered out to an outside service provider. The essence of manufacturing outsourcing is the use of production facilities of different firms instead of using production facilities in-house or making new manufacturing investments (Ehie, 2001, p. 31).

Loh \& Venkatraman (1992) defined IT outsourcing as the "significant contribution by external providers in the physical and/or human resources associated with the entire or specific components of the IT infrastructure in the user organization" (p. 9).

The latest kind of outsourcing is business process outsourcing - BPO, in which the service provider takes responsibility for a whole business process. This type of outsourcing helped popularize the concept of outsourcing beyond the industrial boundaries.

Table 1 Drivers of outsourcing

\begin{tabular}{|c|c|}
\hline Economic factors & Objectives or anticipated outcomes \\
\hline Cost reduction & $\begin{array}{ll}\text { - } & \text { To improve profitability } \\
\text { - } & \text { To improve operating efficiency } \\
\text { - } & \text { To add value to the product }\end{array}$ \\
\hline Cost saving & $\begin{array}{ll}\text { - } & \text { To improve cash flow } \\
\text { - } & \text { To increase efficiency }\end{array}$ \\
\hline $\begin{array}{l}\text { Capital investment } \\
\text { reduction }\end{array}$ & $\begin{array}{l}\text { - } \quad \text { To make capital funds more efficiently } \\
\text { - } \quad \text { To improve return on assets }\end{array}$ \\
\hline Strategic factors & Objectives or anticipated outcomes \\
\hline $\begin{array}{l}\text { Acceleration of business } \\
\text { process reengineering }\end{array}$ & $\begin{array}{ll}\text { - } & \text { To improve performance } \\
\text { - } & \text { To achieve competitive advantage }\end{array}$ \\
\hline Focus on core competence & $\begin{array}{ll}\text { - } & \text { To improve business focus } \\
\text { - } & \text { To increase competitive advantage } \\
\text { - } & \text { To leverage the firm's skills and resources } \\
\text { - } & \text { To enhance customer satisfaction }\end{array}$ \\
\hline Flexibility enhancement & $\begin{array}{ll}\text { - } & \text { To reduce the constraints of organization's own production } \\
\text { capacity } & \\
\text { - } & \text { To convert fixed costs to variable costs } \\
\text { - } & \text { To increase responsiveness to market change } \\
\text { - } & \text { To reduce risks }\end{array}$ \\
\hline Environmental factors & Objectives or anticipated outcomes \\
\hline IT development & $\begin{array}{l}\text { - To meet increasing demand for new information systems and } \\
\text { resources more efficiently and economically }\end{array}$ \\
\hline
\end{tabular}




\begin{tabular}{|l|ll|}
\hline Globalization & - & To help companies gain global competitive advantage \\
\hline Capability of supplier & - & $\begin{array}{l}\text { To enable partners to improve service quality and customer } \\
\text { service and increase competitive advantage }\end{array}$ \\
\hline
\end{tabular}

Source: Lau, C., \& Zhang, J. (2006) Drivers and obstacles of outsourcing practices in China, International Journal of Physical Distribution and Logistic Management, Vol. 36, No. 10, 777

\section{Business process outsourcing}

A business process is a complete, dynamically coordinated set of activities or logically related tasks that must be performed to deliver value to internal or external customers or to achieve other strategic goals (Trkman, 2010). In simple terms, business process outsourcing (BPO) is defined as the movement of a business process from inside the organization to external service providers. BPO is the delegation of a (usually, non-core) business process to an external service provider who owns, administers and manages it. Specifically, BPO involves contracting with one or more BPO service providers for the provision of the execution of business process (Saxena \& Bharadwaj, 2009, p. 688). Business process outsourcing (BPO) occurs when an organization turns over the realization of a particular process (such as design products/services, production, managing human resources, information, financial and physical resources) to a third party that specializes in that process. Using outsourcing, a firm (BPO client) has a benefit from the selected BPO provision which can complete the process more efficiently. BPO client has a possibility to concentrate on its core competency and free limited organizational resources (Brown \& Wilson, 2005, p. 20).

Business process management approach means that a focus is placed on the business process, instead of emphasizing an organization's functional and hierarchical structures (Kohlbacher \& Reijers, 2013). Business process represents an object which is to be managed. There have been a number of classifications of business processes. Following Harmon (2003), the crucial business processes are the following: core processes, enabling processes, and management processes. Keen (1997) suggests that relevant processes are those that create value, processes that provide options, and processes that sustain the value.

All of these classifications have been either from the client perspective or from the service provider perspective. For instance, from the client's perspective, processes have been classified as critical, key, and support (Click \& Duening, 2005). Honess (2003) points out that ' 'business processes within a company have been classified in three categories: 1) core, 2) business critical non-core, and finally, 3) non-core, non-critical." Core processes are seldom outsourced, because they are the very essence of the business and the area that requires the most investment. Therefore, critical and non-critical non-core business processes are suited for outsourcing to a service provider.

Similarly, it is possible to observe processes classifications from the service provider's perspective. This classification divides BPO projects on the basis of the type of product/ service. It includes (Mehta et al., 2006, p. 326): 1) front-office processing, 2) middle-office processing, and 3) back-office processing. Front-office BPO includes customer service and technical support services. Middle-office processing includes services such as banking, insurance, transportation, and utilities. Back-office BPO supports processes as human resources, technical support, customer service, finance or accounting. Back-office processes 
are only a couple of the processes that small and large organizations have been able to outsource to others who specialize in those areas. Removing mentioned processes from their internal operations enables companies to reduce payroll and other overhead costs (Saxena \& Bharadwaj, 2009, p. 693).

Business executives and owners commend process outsourcing as a means of eliminating business processes that are not segment of the core competence of their companies. Organizations are focusing on a few business processes in which they are good (efficient) enough. The organization is focused on business processes in which it has not core competencies to perform efficiently. BPO has several advantages (Alexander \& Young, 1996; Halvey \& Melby, 2005; Brown \&, Wilson, 2005; Click \& Duening, 2005, Krstić, 2012: 1) reduction costs, at the same quality to employ a supplier more specialized; 2) restructuring costs, changing fixed costs by variable costs in terms of services provided; 3 ) improvement of quality, for higher specialization; 4) access to outside expert knowledge; 5) stimulates the local employment through contracts with local firms; 6) standardization and access to scale economies, 7) flushes resources for other purposes; 8) share the risk by flexibility of demand with the supplier company; 9) improving management of difficult functions to handle and 10) starting point for changes in the organization.

\section{Competencies of BPO client and provider}

BPO project analysis and implementation are based on the fact that BPO is a socialtechnical phenomenon. That is, a well executed outsourcing project must involve both social and technical resources of the organization. BPO is transformational for the organization and requires attention to the social and human impacts that accompany business transformation. At the same time, one of the primary enablers of BPO is the set of technologies that have emerged to connect the world in a global communications network. As a social-technical phenomenon, effective BPO management requires a diverse skill set that is not likely to be present in any single individual.

Shi (2007) points out that a BPO service provider's competency in managing business process, competence in technology and other competencies is very important for BPO project success or failure. Accordingly, management competencies form another important variable which determines the success or failure of the BPO project (or the BPO result). Despite the fact that the $B P O$ service providers still concentrate on the level of their products or services, the $B P O$ clients are getting more interested in service providers' competencies, for example, the "accessibility" of the service provider, the efficient delivery of the service provider's solution and expertise in the client's business (Shi, 2007, p. 28).

a. In a BPO initiative, two competencies are the most important for the BPO client business process management competency and outsourcing management competency.

Business process management competencies are at the heart of the BPO project, however it is additionally of real concern toward the client organization. For the client organization, business process management competencies includes: process knowledge, determine the framework of business processes performance in the enterprise, and process performance evaluation (Saxena \& Bharadwaj, 2009, p. 695).

Process knowledge. The business process can be viewed as a complex entity that has a certain structure, so it can be differentiated to: a) elements of the process, b) activities within 
a process, and c) tasks or operations within an activity. Each process can be determined by the following: a) boundary points of the process, b) the transformation of inputs into outputs within the process, c) the feedback, and d) the repetitive nature of the process (Krstic \& Kahrović, 2012, p. 4).

Framework of business process performances. The conceptual framework of business process requires the identification of different dimensions of business process performance, such as (Krstić \& Sekulić, 2013, p. 420): 1) inputs and outputs of the processes and activities within the process, 2) process quality performances (reliability, safety, durability, statistical stability) 3) process quantity performances (volume, scope of activities, scope of services, value flows), 4) temporal performances (speed of execution of activities, delivery time, the duration of execution of operations), 5) value performances (costs of activities, output price, etc.), 6) adaptability (flexibility) performances of a process and its activities, 7) effectiveness of a process, 8) efficiency of a processes, as well as efficiency of activities conducted within that process.

Process performance evaluation. The last and most critical competency for the client is the capability to evaluate a process operating at the desired level of performance to deliver the business benefits it was intended to give. In the event that that does not happen, it is very unlikely that the client will get the intended business benefits when the process is outsourced and operating at a much higher performance level (Power et al., 2006). In short, the candidate process for outsourcing must be formally managed to yield its intended business impacts, before it is outsourced for providing enhanced business benefits. On the other side, for the service provider, the process management competencies assume much more critical role as they form the very basis of service provision.

b. For the service provider, the most critical BPM competencies are process transition and process performance management.

Process transition or movements refers to moving the insourced version of the candidate process from the client site to the service provider site in an commonly agreed upon outsourced form. This apparently simple process movement is indeed very complicated, and even some of the very experienced service providers regularly appears to commit errors in it, at least initially. Its complexity comes out of the following implicit activities: acquiring the process knowledge, if the candidate process is unmanaged at the client organization; enhancing the candidate process so as to bring its performance at the settled upon level; and to implement this improved version of the process at the service provider's site in an error-proof manner so that it can pass the demonstration test.

Process performance management like a competence refers to the capability of improving the operations of the outsourced process to the agreed upon level or even better. The performance measures which need to be managed fall in three categories (Saxena \& Bharadwaj, 2009, p. 697): process cost performance, process output performance and process outcome performance.

\section{BPO relationship management}

$\mathrm{BPO}$ relationship management is challenge to both the outsourcing client and the service provider. Unlike the conventional buyer-supplier relationship, the BPO relationship 
must be orderly arranged from the beginning of the BPO project with a strategic intent. Very often, BPO initiative concentrates on the contractual structure used to formalize the BPO arrangement. The contractual structure may not adequately adjust incentives over the organizations, nor effectively coordinate their activities. BPO relationship management includes four crucial characteristics: depth and scope of relationship, choice of assets to use and adopted business culture (Saxena \& Bharadwaj, 2009, p. 698).

Gottschalk \& Solli-Saether (2006) differentiated the four maturity levels of BPO relationships: a) supplier relationship; b) extended supplier relationship; c) partner relationship; and d) strategic partner relationship.

Supplier relationship is generally described by the service provider having a costplus strategy. Extended supplier relationship is portrayed by delivering services in full, on-time and to the specifications. It includes meeting and servicing process outsourcing requirements through cost reduction and value adding initiatives, such as service enhancements, maximizing responsiveness, etc. Partner relationship is described by high client's dependence on the quality, consistency, reliability and dependability of external skills and services to ensure that client meets their own business requirements. Strategic partner relationship, which is the highest level of relationship maturity, is portrayed by all the "win-win" collaborating relationship, as well as shared visions, strategies and information sharing among the client and the service provider.

\section{Implementation of BPO initiative}

The decision to implement a BPO initiative for any firm has far-reaching risks and consequences. At the same time, these implications of the decision-making process should not lead to paralysis - there are too many possible benefits to fall into the trap of doing nothing. It is important for decision makers to recognize that undertaking a BPO initiative is a strategic action.

The most effective way to realize a BPO initiative is to use a systematic approach that minimizes risks. It is possible to develop and recommend a four phases for analyzing and selecting the BPO initiative. These phases have been designed to integrate and align the decision-making process with long-term organizational strategic objectives and near-term organizational needs. Each phase is design to help organizations link BPO decision making to overall organizational strategy. BPO project has the following phases or steps:

- Establish a business process outsourcing team;

- Conduct a analysis ot business process performances;

- Determine possibilities for BPO;

- Develop and present the plan of BPO.

Although these steps seem transparent, many organizations overlook opportunities or misunderstand the true value and risks of skipping steps in the analysis. An organization can be in confusion, if it uses nonsystematic approach.

Establish a business process outsourcing team. As discussed earlier, multidisciplinary nature of BPO project requires a set of various process management competencies in order effective managing with it. Besides that, BPO imply forming a multidisciplinary team to adequately assess the outsourcing opportunity. Basic characteristic of outsourcing team highlights the need for interdisciplinary skills to manage a BPO project effectively. 
Business process outsourcing team should be supervised by the top management and the chief process officer (or, so called proces owner). The chief process officer oversees process management so that it increase performance and ensures value creation by executing the business process strategy across organizational boundaries, such as department or functions (Rosing et al., 241-242). This team should consists of not more than ten individuals who represent a range of existing business process in an organization (Click \& Duening, 2005, p. 51). It is also good to include people who have demonstrated an ability to adjust and change through previous BPO project. Preparation and training of the team are imperative for success. Team members must be knowledgeable about the organization's overall strategic intent, as well as potential advantages and disadvantages of BPO.

Business process (performance) analysis is a critical component of any BPO initiative. It refers to the exercise of examining, mapping, and categorizing internal business processes. Namely, this exercise involves mapping of business processes. The goal is understanding of how work flows within the organization or how an organization operate. This is often a difficult task, requiring hard thinking and involving individuals who are not the members of the BPO team. Good realised business process analysis can unveil hidden bottlenecks and expose inefficient procedures that have become entrenched within the organization.

Business processes mapping refers to the step-by-step description of the tasks and actions taken by workers as they use a specific set of inputs to produce a defined set of outputs. The main purpose of business process mapping is to help organizations in becoming more efficient. A clear and detailed business process map or diagram allows improvements of the current process. Many diagrams and tools are used for purposes of detecting the BPO opportunity. The objective of process mapping is to define clearly the activities within a process which is mapped, and to identify responsible persons for partial activities within an process. Identifying responsible people is a critical element of mapping, because these individuals or groups can dramatically influence the effectiveness of the overall BPO project.

The result of the mapping process is the identification and classification of business process in three group: critical, key and support. Critical business processes are those that are very important to a company's core business. Critical processes are those that must be performed nearly flawlessly and they are potential candidates to become a future core competence, if competitive conditions in the next period would be changed. For example, a firm that excels in logistics function may one day become a logistics firm.

Key processes are those that are important to the organization core business. A key function is one that people within the organization can readily identify and usually also know who is responsible for it. Support processes are necessary for the organization to function effectively. When business processes are identified and classified, the business process outsourcing team begins to develop a feel for which processes may be candidate for outsourcing.

Determine BPO possibilities. Selecting the business process to outsource must take multiple factors into consideration (Yang et al., 2006, p. 3770): expectation (cost savings, focus on core competence, flexibility), risk (information security, loss of management control, labor union, moral problem), and environment (provider's service quality, market maturity, other's firm outsourcing decisions). The reasons for organization's outsourcing 
include the following: cost savings, a focus on core competence, and adaptability in management. In any case, management needs to carefully consider the related shortcomings alongside the expected benefits. The generally perceived disadvantages include information security and loss of management control. Furthermore, labor unions and problems in morale could also become risk factors in the case of BPO.

Very important task in this step is a systematic approach to identifying and selecting the right outsourcing partner - service provider. This task contains eight steps (Click \& Duening, 2005, p. 94): 1) appointment a service providers team, 2) establish qualifications, 3) develop a long list, 4) distribute the request for information, 5) distribute the request for proposals, 6) evaluate proposals, 7) select a short list, and 8) select a service provider.

Develop and present the plan of BPO. The final step in the BPO opportunity analysis is to develop a business plan for decision makers that will include direct recommendations on which, if any, business processes within the organization are suitable for outsourcing. A business plan is a written document that presents the methodology and finding business process outsourcing team. The methodology of the setting up the BPO plan should include a review of the process, as well as: a) The people who were consulted during the analysis phase; b) The list of used documents, books and other in research; c) An overview of analytic tools which are applied in order to BPO opportunity identification and selection of the best opportunity; d) Copies of documents which are used in gathering the original data.

The business plan should also include the business model for each process recommended for outsourcing. The model will highlight in summary the costs, timing, and deliverables associated with each process. Detailed transition models should be kept on reserve for those decision makers who wish to have more information. Finally, the business plan should make explicit the goals of outsourcing for each process. The goal may be to reduce operating costs, but it may also include the opportunity to develop worldclass capability in a critical process, to reduce cycle times, or simply to free up business resources for other applications. Whatever the reason, the business plan should clearly state the likely improvements that may be attained through a BPO service provider.

\section{Conclusion}

This paper proposes business process outsourcing as a strategic option for companies for the realization of a competitive strategy based on organizational capabilities and proposes a conceptual model for business process outsourcing. Outsourcing enables organizations to consistently perform the outsourced business process more effectively than any of their competitors. Suggested model has explained in four steps: planning the outsourcing of business process, establish a business process outsourcing team, discover potential possibilities of business process outsourcing and develop and present the business plan. This model of business process outsourcing can be used by both the BPO clients and service providers for successfully achieving the intended business outcomes as well as for enhancing their competitiveness. It is hoped that the model proposed in the paper will be increasingly adopted in forthcoming BPO projects and will be found helpful in making these projects successful. 


\section{References}

Alexander, M., Young, D. (1996) Strategic outsourcing, Long Range Planning, Vol. 29, No. 1, 116-119.

Armistead, C., Rowland, P. (1996) Managing Business Processes: BPR and Beyond, John Wiley \& Sons.

Bhattacharya, R., Behara, R., Gundersen, D. (2003) Business risk perspectives on information systems outsourcing, International Journal of Accounting Information Systems, Vol. 4, No. 1, 75-93

Brown, D., Wilson, S. (2005) The Black Book of Outsourcing - How to Manage the Changes, Challenges, and Opportunities. John Wiley \& Sons. Hoboken, New Jersey.

Chew, E., Gottschalk, P. (2013) Knowledge Driven Service Innovation and Management: IT Strategies for Business Alignment and Value Creation, IGI Global.

Click, R., Duening, T. (2005) Business Process Outsourcing the Competitive Advantage. John Wiley \& Sons. Hoboken, New Jersey.

Ehie, I. (2001). Determinants of success in manufacturing outsourcing decisions: A survey study, Production and Inventory Management Journal, Vol. 42, No. 1, 31-39.

Ghodeswar, B., Vaidyanathan, J. (2008) Business process outsourcing: an approach to gain access to world-class capabilities, Business Process Management Journal, Vol. 14, No. 1, 23-38.

Halvey, J., Melby, B. (2005) Information Technology Outsourcing Transactions: process, strategies and contracts. John Wiley \& Sons. Hoboken, New Jersey.

Harmon, P. (2003) Business Process Change: A Manager's Guide to Improving, Redesigning, and Automatic Processes. Morgan Kaufmann Publishers. San Francisco.

Hatten, K., Rosenthal, S. (1999) Managing the Process-centred Enterprise, Long Range Planning, Vol. 32, No. 3, 1999, 293-310.

Honess, S. (2003) Business process outsourcing, in Angel, J. (Ed.), Technology Outsourcing, The New Society, London, 208-229.

Gottschalk, P., Solli-Saether, H. (2006) Maturity model for IT outsourcing relationships, Industrial Management \& Data Systems, Vol. 106, No. 2, 200 - 212.

Keen, P. (1997) The Process Edge-Creating Value Where It Counts. Harvard Business School Press. Boston.

Kohlbacher, M., Reijers, H. (2013) The effect of process-oriented organizational design on firm performance, Business Process Management Journal, Vol. 19, No. 2, 245-262.

Krstić, B., Sekulić, V. (2013) Upravljanje performansama preduzeća, Ekonomski fakultet, $\mathrm{Niš}$

Krstić, B. (2012) Uloga strategijske kontrole u unapređenju poslovnih performansi, Ekonomski fakultet, Niš

Krstić, B., Jovanović, S., Kahrović, E. (2012) Process-oriented enterprise as a determinant of organization behavior in contemporary business term, Actual Problems of Economics, No. 11 (137), 369-379. 
Krstić, B., Vučić, S. (2003) Neke implikacije strategije spoljnih izvora resursa i sposobnosti na efikasnost preduzeća, Ekonomske teme, No. 4, 2003, 93-102.

Loh, L., Venkatraman, N. (1992) Determinants of Information Technology Outsourcing: A Cross-Sectional Analysis, Journal of Management Information Systems, Vol. 9, No. 1, 7-24.

Lau, C., Zhang, J. (2006) Drivers and obstacles of outsourcing practices in China, International Journal of Physical Distribution and Logistic Management, Vol. 36, No. 10, 776-792.

Mahmoodzadeh, E., Jalalinia, S., Yazdi, F. (2009) A business process outsourcing framework based on business process management and knowledge management, Business Process Management Journal, Vol. 15, No. 6, 845-864.

Maurice, F., Greaver, II. (1999) Strategic Outsourcing - A Structured Approach to Outsourcing Decisions and Initiatives. AMACOM, New York.

Mehta, A., Armenakis, A., Mehta, N., Irani, F. (2006) Challenges and Opportunities of Business Process Outsourcing in India, Journal of Labor Research, Vol. 27, No. 3, 323-338.

Power, M., Desouza, K., Bonifazi, C. (2006) The Outsourcing Handbook: How to Implement a Succesfull Outsourcing Process, Kogan Page, London.

Rosing, M., Scheer, A., Scheel, H. (2014) The Complete Business Process Handbook, Morgan Kaufmann, London.

Saxena, K., Bharadwaj, S. (2009) Managing business process through outsourcing: a strategic partnering perspective, Business Process Management Journal, Vol. 15, No. 5, 687-715.

Shi, Y.(2007) Today's solutions and tomorrow's problem: the business process outsourcing risk management puzzle, California Management Review, Vol. 49, No. 3, $27-44$.

Trkman, P. (2010) The critical success factors of business process management, International Journal of Information Management, Vol. 30, No. 2, 125-134.

Weske, M. (2012) Business process management - concepts, languages, arhitectures, Springer.

Yang, D., Kim, S., Nam, C., Min, J. (2006) Developing a decision model for business process outsourcing, Computers \& Operations Research, Vol. 34, No. 12, 3769-3778. 